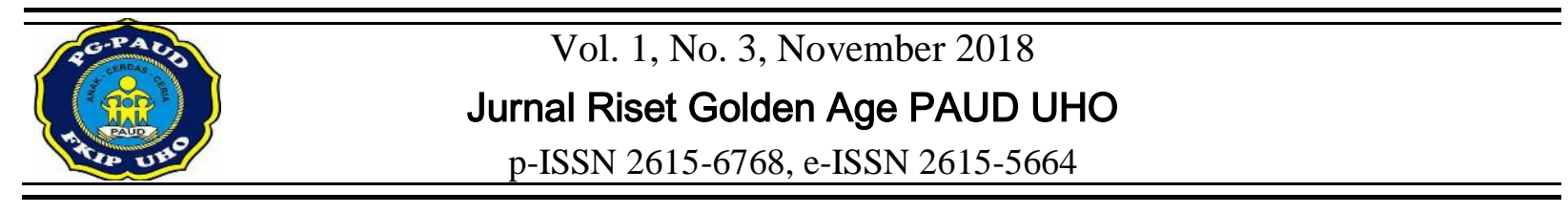

\title{
MENINGKATKAN KEMAMPUAN SOSIAL EMOSIONAL ANAK MELALUI METODE
} PROYEK

\author{
Sri Masjuanti ${ }^{1)}$, Nurhayati ${ }^{1)}$ \\ ${ }^{1}$ Jurusan PG-PAUD, Universitas Halu Oleo. Jln. H.E.A Mokodompit, Kendari 93232, Indonesia.
}

\begin{abstract}
Abstrak
Penelitian ini bertujuan untuk meningkatkan kemampuan sosial emosional anak melalui metode proyek di kelompok B TK Negeri Pembina Raha Kabupaten Muna. Penelitian ini merupakan penelitian tindakan kelas (PTK) yang dilakukan dalam dua siklus. Jenis penelitian ini adalah penelitian tindakan kelas (PTK). Penelitian ini dilaksanakan dalam dua siklus. Tahap-tahap dalam penelitian ini mengikuti prosedur penelitian tindakan kelas. Tahapan dalam penelitian ini yaitu: (1) perencanaan, (2) pelaksanaan tindakan, (3) observasi dan evaluasi, dan (4) refleksi. Subjek dalam penelitian ini adalah guru dan anak dikelompok B TK Negeri Pembina Raha, yang berjumlah 20 orang anakyang terdiri atas 8 orang anak laki-laki dan 12 orang anak perempuan. Berdasarkan hasil analisis data pada aktivitas belajar anak didik pada siklus I dari 14 aspek diperoleh persentase ketercapaian sebesar 64,3\% atau 9 aspek yang tercapai. Sedangkan aktivitas belajar anak pada siklus II mengalami peningkatan menjadi sebesar $85,7 \%$ atau 12 aspek yang terlaksana. Dengan demikian dapat disimpulkan bahwa peningkatan kemampuan sosial emosional anak di kelompok B TK Negeri Pembina Raha Kabupaten Muna dapat ditingkatkan melalui metode proyek.
\end{abstract}

Kata kunci: Kemampuan Sosial, Emosional, Metode Proyek

\section{IMPROVING THE SOCIAL EMOTIONAL ABILITY OF CHILDREN THROUGH THE PROJECT METHOD}

\begin{abstract}
The purpose of this study is to improve children's emotional social ability through the project method in Group B TK Negeri Pembina Raha in Muna. The type of this research is a classroom action research. The study was conducted in two cycles. The steps in this study follows the classroom asction research procedures. The stages in this research are: (1) planning, (2) action implementation, (3) observation and evaluation, and (4) reflection. The subjects in this study were the teachers and children in Group B TK Negeri Pembina Raha, which amount to 20 children consist of 8 boys and 12 girls. Based on the result of the learning activities of students in the first cycle of 14 aspects obtained achievement percentage of $64.2 \%$ or 9 aspects achieved. While the learning activity of children in the secnd cycle has improved as equal as $85.7 \%$ or 12 aspects that have been done. It can be conclude that the improvement of emotional social ability of chidren in Group B TK Negeri Pembina Raha in Muna can be improved through the project method.
\end{abstract}

Keywords: Social Ability, Emotional, The Project Method.

\section{PENDAHULUAN}

Menurut Undang-Undang Nomor 20 Tahun 2003 tentang Sistem Pendidikan Nasional pasal 1 ayat 14 disebutkan bahwa pendidikan anak usia dini adalah suatu upaya pembinaan yang ditujukan kepada anak sejak lahir sampai usia enam tahun, yang dilakukan melalui pemberian rangsangan pendidikan untuk membantu pertumbuhan dan perkembangan jasmani dan rohani, agar anak memiliki kesiapan dalam memasuki pendidikan lebih lanjut (Dikdasmen, 2010 : 1).

Pendidikan merupakan kebutuhan dasar manusia yang harus terpenuhi oleh semua orang. Setiap individu memiliki hak untuk belajar. Belajar adalah suatu proses ditandai dengan adanya perubahan pada diri seseorang, perubahan sebagai hasil proses belajar yang ditunjukan dalam berbagai bentuk seperti perubahan pengetahuan, pemahaman, sikap dan tingkah laku, keterampilan, kecakapan, 
kebiasaan, serta perubahan aspek-aspek yang ada pada individu yang belajar (Sudjana, 1996: 2).

Pendidikan anak usia dini adalah pendidikan yang paling mendasar dan menempati kedudukan sebagai "golden age" dan sangat strategis dalam pengembangan sumber daya manusia (Yamin, 2010: 1). Rentang anak usia dini dari lahir sampai berusia enam tahun adalah usia kritis sekaligus strategis dalam proses pendidikan dan dapat mempengaruhi proses serta hasil belajar seseorang. Pada umumnya usia golden age, anak mempunyai absorbent mind yang baik, artinya otak mereka mampu menyerap dengan cepat segala pengetahuan dan keahlian yang baru.

Anak usia dini mempunyai beberapa aspek perkembangan yang perlu ditingkatkan. aspek perkembangan anak meliputi perkembangan kemampuan fisik-motorik, perkembangan kemampuan kognitif, perkembangan kemampuan bahasa, dan perkembangan kemampuan sosial emosional Wortham (Ramli, 2005: 50)

Kemampuan sosial emosional merupakan kemampuan anak untuk menyesuaikan diri terhadap dunia sosial yang lebih luas dimasyarakat sekitar (Soejatiningsih 2012: 246).

Kemampuan sosial emosional menurut Harlock menyebutkan " kerjasama, persaingan, kemurahan hati, hasrat akan penerimaan sosial, simpati, empati, ketergantungan sikap ramah, sikap tidak mementingkan diri sendiri, meniru prilaku kelekatan. Berdasarkan pola pikir sosial tersebut terlihat bahwa anakmulai menunjukan rasa ingin tahu mereka dan merasa ingin di terima oleh orang lain.

Kemampuan sosial anak usia dini diarahkan untuk pengembangan sosial yang baik, seperti kerja sama, tolong menolong, berbagi, simpati, empati dan saling membutuhkan satu sama lain. Untuk itu, sasaran pengembangan perilaku sosial pada anak usia dini adalah untuk berketerampilan berkomunikasi, keterampilan memiliki rasa senang dan periang, menjalin, persahabatan, memiliki etika tata karma yang baik. Dengan demikian, materi perkembangan sosial yang diterapan taman kanak-kanak meliputi: disiplin, kerja sama, tolong menolong, empati, dan tanggung jawab.

Kemampuan emosional adalah reaksi yang terorganisasi terhadap hal-hal yang berhubungan kebutuhan, tujuan, ketertarikan, dan minat induvidu. Perilaku emosional tampak sebagai akibat dari emosi seseorang. "Emosi oleh juntika didefinisikan sebagai suatu suasana yang kompleks dan getaran jiwa yang menyertai atau muncul sebelum/sesudah terjadinya perilaku"

Berdasarkan uraian di atas dapat di pahami bahwaemosional merupakan proses yang ditandai dengan adanya perubahan berbagai emosional anak seperti takut, cemas, marah, murung, kesali, iri, cemburu, senang kasih sayang, dan ingin tahu. Perubahan sifat anak harus disertai usaha guru untuk menumbuh kembangkan kemampuan emosional anak. Sebagai hasil pengalaman dan latihan untuk memperoleh kemampuan sosial emosional anak.

Berdasarkan hasil observasi awal yang telah dilakukan di kelompok B TK Negeri Pembina Raha Kabupaten Muna dalam meningkatkan kemampuan sosial emosional anak masih rendah, hal ini ditandai dengan kondisi pada saat melakukan observasi awal yang dilakukan peneliti di TK Negeri Pembina Raha Kabupaten Muna menunjukan bahwa dari 20 anak didik terdapat 10 anak atau sekitar 50\% dengan kriteria memiliki kemampuan sosial emosional sehingga dapat dikatakan bahwa kemampuan sosial emosional anak belum mencapai tingkat perkembangan yang diharapkan yaitu kriteria Berkembang Sangat Baik (BSB) dan Berkembang Sesuai Harapan (BSH), selanjutnya sekitar 10 anak atau sekitar $50 \%$.

Salah satu upaya rendahnya Kemampuan sosial emosional anak pada Kelompok B TK Negeri Pembina Raha adalah dengan memilih metode pembelajaran yang relevan. Metode pembelajaran dimaksud antara lain adalah metode Bermain Proyek.

Metode proyek adalah metode yang memberikan kesempatan kepada anak untuk menggunakan lingkungan dan alam sekitar serta kegiatan sehari-hari sebagai bahan pembahasan melalui serangkaian kegiatan (Harianti 1994: 148).

Metode proyek adalah metode yang memberikan kesempatankepada peserta didik untuk melakukan aktivitas belajar secara bertahap, dari tahapan awal sampai tahapan akhir yang merupakan satu kesatuan rangkaian kegiatan. Metode merupakan alam sekitar dan kegitan sehari- hari yang sederhana untuk dilakukan oleh peserta didik misalnya menanam 
tanaman yanbg mudah tumbuh dengan biji (kacang hijau).

Metode proyek merupakan salah satu cara memberian pengalaman belajar dengan menghadapkan dengan persoalan sehari-hari yang harus dipecahakan secara berkelompok.

Metode proyek berasal dari gagasan "John Dewey tentang konsep yakni proses perolehan hasil belajar dengan mengerjakan tindakan-tindakan tertentu sesuai dengan tujuannya., terutama proses penguasaan anak tentang bagaimana sesuatu pekerjaan yang terdiri atas serangkaian tingkah laku untuk mencapai tujuan, misalnya melipat kertas, memasang tali sepatu, menganyam membentuk model bintang atau bangunan, dan sebagainya"

Metode proyek merupakan salah satu cara pemberian pengalaman belajar pada anak. Anak langsung dihadapkan pada persoalan sehari-hari yang menuntut anak untuk melakukan berbagai aktivitas sesuai dengan proyek yang diberikan. Dari aktivitas tersebut anak memperoleh pengalaman yang akan membentuk perilaku sebagai kemampuan yang dimiliki.

Penggunaan metode proyek selalu dalam kegitan kelompok. Dalam situasi bekerja kelompok anak belajar sebgai tanggung jawab, membina hubungan menghargai orang lain.

Menurut Masitoh "metode proyek memberikan kebebasan kepada anak untuk melakukan kegiatan yang sesuai dengan minatnya masing-masing". Anak dituntut untuk bertanggung jawab dan memiliki motivasi agar dapat menyelesaikan pekerjaannya. Dalam meningkatkan kebebasan anak akan mempengaruhi peranan guru, pada kegiatan ini guru memfasilitator yang akan memberikan kemudahan kepada anak untuk belajar, sementara anak memiliki kebebasan untuk melakukan kegiatan sesuai dengan keinginan mereka.

Dengan metode proyek memberikan peluang kepada anak untuk meningkatkan keterampilan yang telah dikuasai secara perseorangan atau kelompok kecil, dan menimbulkan minat anak terhadap apa yang dilakukan dalam proyek, serta peluang bagi anak untuk mewujudkan daya kreativitasnya, bekerja sama secara tuntas, dan bertanggung jawab atas keberhasilan tujuan kelompoknya.

Penulis menyimpulkan bahwa metode proyek merupakan salah satu cara yang dapat dalam pengajaran untuk melatih kemampuan anak memecahkan masalah dalam kehidupan sehari-hari dan dapat menggerakan anak dalam bekerja sama dengan anak yang lain dimana masing-masing bagian pekerjaannya secara individual atau dalam kelompok kecil untuk mencapai tujuan yang menjadi milik bersama.

\section{METODE}

Arikunto (2010: 135) menyatakan bahwa penelitian tindakan kelas (classroom action research) adalah penelitian yang dilakukan oleh guru ke kelas atau di sekolah tempat iamengajar dengan penekanan pada penyempurnaan atau peningkatan proses dan praksis pembelajaran.

Penelitian ini dilaksanakan di Taman TK Negeri Pembina Raha. Waktu penelitian tindakan kelas ini di laksanakan pada semester genap tahun pelajaran 2016/2017 yaitu padabulan Maret - April 2017

Subjek penelitian tindakan kelas ini adalah guru dan anak di Kelompok B TK Negeri Pembina Raha dengan 20 anak, yang terdiri dari 12 anak perempuan dan 8 anak laki-laki dengan rentang usia 5-6 tahun..

Adapun faktor-faktor yang diteliti dan diamati dalam penelitian ini adalah sebagai berikut:

1. Faktor guru, aktivitas mengajar guru melalui kegiatan pengelompokkan benda dapat meningkatkan kemampuan kognitif anak di TK Negeri Pembina Raha.

2. Faktor anak, aktivitas belajar dan hasil belajar anak dalam mengikuti kegiatan pembelajaran dalam meningkatkan kemampuan kognitif anak di Kelompok B TK Negeri Pembina Raha.

3. Hasil belajar anak tentang peningkatan kemampuan kognitif anak melalui kegiatan pengelompokkan benda.

Pengumpulan data dalam penelitian ini dihimpun melalui hasil observasi, dokumentasi dan wawancara. Observasi adalah suatu teknik yang dapat dilakukan guru untuk mendapatkan berbagai informasi atau data tentang peremabangan dan permasalahan anak. Melalui pengamatan, guru dapat mengetahui perkembangan yang terjadi pada anak dalam kurun waktu tertentu (Wahyudin dan Mubiar, 2011:59). Observasi dilakukan oleh guru Kelompok B sebagai observer dengan menggunakan lembar observasi. Penggunaan lembar observasi ini untuk melihat proses pelaksanaan pembelajaran yang dilaksanakan oleh guru ketika melakukan kegiatan 
pengelompokkan benda untuk meningkatkan kemampuan kognitif anak. Dokumentasi yaitu mencari data mengenai hal-hal atau variable yang berupa catatan, transkrip, buku, surat kabar, majalah, prasasti, notulen rapat, lengger, agenda dan sebagainya (Arikunto, 2010: 274). Dokumentasi ini berupa foto guru/peneliti pada saat proses meneliti sebagai bukti dalam melakukan kegiatan penelitian di lapangan. Wawancara adalah suatu tehnik pengumpulan data yang dapat dilakukan guru untuk mendapatkan informasi tentang perkembangan dan permasalahan anak dengan cara melakukan percakapan langsung, baik dengan anak maupun orang tua.

Pengolahan data dalam penelitian ini disesuaikan dengan teknik penilaian di TK yaitu dengan menggunakan tanda sebagai berikut: * = belum berkembang (BB), $* *=$ mulai berkembang $(\mathrm{MB}), * * *=$ berkembang sesuai harapan $(\mathrm{BSH})$, **** = berkembang dengan baik (BSB) (Depdiknas, 2004: 26).

Pengelolaan data dalam penelitian ini disesuaikan dengan teknik penilaian di TK yaitu dengan menggunakan tanda sebagai berikut: Belum Berkembang $(\mathrm{BB})=*$, Mulai Berkembang $(\mathrm{MB})=* *$, Berkembang Sesuai Harapan $=* * *$, Berkembang Sangat Baik $=* * * *$ (Depdiknas, 2004: 26).

Dari segi indikator hasil, tindakan dikatakan berhasil apabila anak didik telah mencapai nilai berkembang sesuai harapan (BSH) dan berkembang sangat baik (BSB) minimal $75 \%$ baik secara individual maupun klasikal.

\section{HASIL DAN PEMBAHASAN}

Hasil yang diperoleh terhadap kemampuan sosial emosional melalui metode proyek pada observasi awal jika dibandingkan dengan pelaksanaaan siklus I terlihat adanya peningkatan, namun belum mencapai indikator kinerja yang diharapkan, sehingga perlu dilaksanakan siklus II. Hal ini disebabkan pada pelaksanaan siklus I terdapat beberapa kelemahan guru dalam proses pembelajaran, dimana guru belum maksimal dalam menyampaikan tujuan pemebelajaran pada anak, guru belum memberikan penguatan/penghargaan kepada anak, serta guru belum maksimal dalam menyimpulkan kegiatan pembelajaran. Sehingga perlu dilakukan sesuatu perbaikan pada siklus II agar indikator kinerja yang diharapkan dapat tercapai.
Dapat diketehui perbandingan jumlah anak yang memiliki kemampuan sosial emosional melalui metode proyek dengan kriteria Berkembang Sangat Baik (BSB) dan Berkembang Sesuai Harapan (BSH), sebelum tindakan observasi awal sebanyak 8 orang anak, yang terdiri dari $(\mathrm{BSB})=2$ orang anak, $(\mathrm{BSH})=$ 6 orang anak, setelah pelaksanaan siklus I mengalami Peningkatan sebanyak 13 orang anak, yang terdiri dari $(\mathrm{BSB})=3$ orang anak, $(\mathrm{BSH})=10$ orang anak, dan pada siklus II meningkat menjadi 17 orang anak, yang terdiri dari $(\mathrm{BSB})=5$ orang anak, $(\mathrm{BSH})=12$ orang anak.

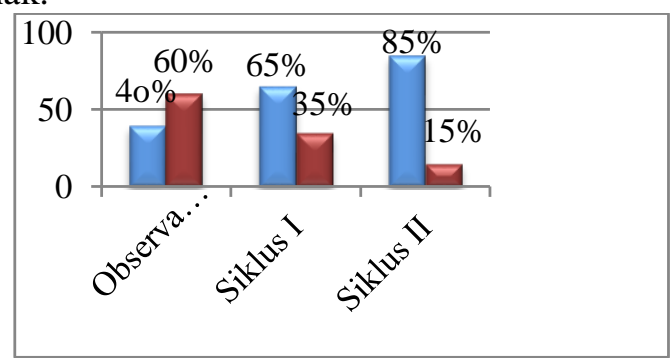

\section{Gambar 1. Histogram Hasil Analisis Kemampuan Sosial Emosional Anak Melalui Metode Proyek.}

Selama kegiatan penelitian berlangsung, dari data hasil yang diperoleh sebagaimana dideskripsikan pada halaman sebelumnya, dapat dikatakan bahwa kegiatan pembelajaran dalam meningkatkan kemampuan sosial emosional melalui metode proyek yang dirancang dan dilaksanakan oleh peneliti yang bekerjasama dengan guru Kelompok B TK Negeri Pembina Raha sebagai observer pada setiap pelaksanaan pembelajaran siklus I dan siklus II, sangat memberikan manfaat pada anak dan peneliti melalui pengalaman langsung, serta kemampuan sosial emosional anak yang mengalami peningkatan.

Jika dilihat dari pemahaman anak mulai dari pelaksanaan siklus I sebesar $65 \%$ jika dibandingkan pada tahapan observasi awal penelitian yang hanya mencapai $40 \%$ dan pada tindakan siklus II mencapai persentase sebesar $85 \%$, menunjukkan hasil yang lebih baik dari sebelumnya, karena indikator kinerja yang ditetapkan telah tercapai yaitu minimal $75 \%$ maka penelitian ini dapat dihentikan.

\section{KESIMPULAN DAN SARAN}

\section{Kesimpulan}


Berdasarkan hasil penelitian yang dilakukan di TK Negeri Pembina Raha pada Kelompok B, maka dapat disimpulkan bahwa kemampuan sosial emosional anak dapat ditingkatkan melalui metode proyek. Hal ini dapat terlihat oleh adanya peningkatan kemampuan sosial emosional anak pada saat observasi awal sebesar $40 \%$, pada siklus I meningkat menjadi $65 \%$ dan pada siklus II lebih meningkat menjadi $85 \%$.

\section{Saran}

Peneliti menyarankan hal-hal diantaranya: (1) diharapkan kepada guru, dalam pelaksanaan pembelajaran hendaknya mempertimbangkan materi, media, dan strategi yang tepat untuk anak didik dan guru dituntut untuk selalu kreatif dan inovatif dalam melaksanakan kegiatankegiatan yang dapat meningkatkan seluruh aspek perkembangan anak; (2) bagi sekolah, diharapkan dapat menuntut tenaga pendidik menjadi guru yang kreatif, inovatif dalam pengembangan kegiatan-kegiatan pembelajaran untuk anak sesuai dengan tahap perkembangan dan kebutuhan anak.

\section{DAFTAR PUSTAKA}

Arikunto, Suharsimi 2010. Prosedur Penelitian Suatu Pendekatan Praktek. Jakarta: Rineka Cipta.

Dewey, John. 2010. Strategi Pembelajaran Berbasisi Masalah. Jakarta: Departemen Pendidikan Nasional.

Dikdasmen. 2010. Pedoman Pengembangan Program Pembelajaran di Taman Kanak-kanak. Jalarta Kemendiknas.

Harianti. 1994. Program Kegiatan Belajar Taman Kanak-Kanak. Jakarta: Departemen.

Kusumah, Wijaya, dkk. 2012. Mengenal Penelitian Tindakan Kelas Edisike II. Jakarta: PT. Indeks.

Martinis, Yamin. 2010. Strategi Pembelajaran berbasis Kompetensi. Jakarta: Gaung Persada Pers.

Masitoh, dkk. 2005. Pendekatan Belajar Aktif Di Taman-Taman Kanak-Kanak. Jakarta: Departemen Pendidikan Nasional.
Ramli, Mansur. 2005. Pendampingan Perkembangan Anak Usia Dini. Jakarta: Dirjen Dikti PPLPTK Departemen Pendidikan dan Kebudayaan.

Soejatiningsih, Cristian Hari N. 2012. Perkembangan Anak Sejak Pembuahan Sampai dengan Kanak-kanak Akhir. Jakarta: Prenada Media Group.

Sudjana, Nana. 1996. Evaluasi Pemebelajaran. Yogyakarta: Multi Pressindo. 